\title{
Almond Leaf Scorch Disease Development on Almond Branches High-Grafted on Peach Rootstock
}

Tiesen Cao, Department of Agricultural, Food and Nutrition Science, University of Alberta, Edmonton, AB T6G 2P5 Canada; and Theodore M. DeJong, Department of Plant Sciences, and Bruce C. Kirkpatrick, Department of Plant Pathology, University of California, Davis 95616

\begin{abstract}
Cao, T., DeJong, T. M., and Kirkpatrick, B. C. 2013. Almond leaf scorch disease development on almond branches high-grafted on peach rootstock. Plant Dis. 97:277-281.

Development of almond leaf scorch (ALS) disease was monitored on young almond (Prunus dulcis 'NePlus' and 'Peerless') shoots produced from almond scion wood that was high-grafted on peach rootstocks ( $P$. persica 'Queencrest/Nemaguard'), after the almond shoots were mechanically inoculated with Xylella fastidiosa. The objective of this study was to evaluate the potential movement of $X$. fastidiosa through almond-peach graft unions. ALS symptoms developed on both $X$. fastidiosa-inoculated and uninoculated almond shoots that were high-grafted on different peach limbs of the same tree in September following inoculations with X. fastidiosa made in June and July 2002, respectively, when the average distance in peach rootstock between the two almond-peach graft unions was $30.5 \mathrm{~cm}$ or shorter. No ALS symptoms were observed on uninoculated almond shoots late in the growing season of the second year. The incidence of ALS-affected leaves on shoots inoculated with $X$. fastidiosa decreased in the second year on

the inoculated shoots of Peerless as determined by the number of inoculated shoots showing ALS symptoms in 2002 versus 2003. No visible ALS symptoms were observed in NePlus late in the growing season of the second year, suggesting that survival of $X$. fastidiosa in NePlus was less than in Peerless. These data demonstrate that movement of $X$. fastidiosa through two almond-peach graft unions was possible during the year of inoculation when the peach rootstock stem distance between the two almond-peach graft unions was minimal. However, $X$. fastidiosa may not survive the winter season or survived so poorly as not to be able to produce ALS symptoms in the second growing season on the uninoculated shoots that previously showed ALS symptoms in the fall of the year when an adjacent shoot was inoculated. The results suggest that high-grafting almond scion wood on multiple peach rootstock limbs may provide a means to limit movement of $X$. fastidiosa from one almond limb to another on the same tree.
\end{abstract}

Almond leaf scorch (ALS) is a persistent disease that causes general growth decline, decreased productivity, and, in some cases, death of affected almond trees. Newly infected trees usually exhibit leaf scorch symptoms on a single terminal branch in July or August. Later in the same season or in subsequent years, adjacent branches may become affected. Eventually, the whole tree may be systemically infected, often within 2 to 5 years (26). ALS is caused by Xylella fastidiosa Wells et al. (44), which can be graft transmitted by buds, bud chips, or stems from naturally or experimentally infected trees to healthy 1- and 2-year-old almond trees (26). ALS has been observed to develop slowly through an orchard but significantly decreases productivity of orchards in 10 to 15 years $(34,37,38)$.

$X$. fastidiosa, a gram-negative, xylem-limited, insect-transmitted bacterium, also causes diseases in many other agriculturally important plants such as grapevine, citrus, coffee, peach, and plum $(2,11,17,22)$. Strains of $X$. fastidiosa are classified into different subspecies that differ genetically and, in some cases, infect different plant hosts (35). Strains of X. fastidiosa that cause Pierce's disease (PD) in grapevine and strains that cause ALS are classified as $X$. fastidiosa subsp. fastidiosa and $X$. fastidiosa subsp. multiplex, respectively (19,35). In California, X. fastidiosa subsp. multiplex (almond strain) has never been isolated from grape plants, although $X$. fastidiosa subsp. fastidiosa (grape strain) has been occasionally found in almond plants $(3,7)$. Strains of $X$. fastidiosa subsp. multiplex that cause phony peach and plum leaf scald diseases can be graft transmitted such that plum strains can cause phony peach and

Corresponding author: T. Cao, E-mail: tiesen.cao@ualberta.ca

Accepted for publication 3 September 2012.

http://dx.doi.org/10.1094/PDIS-06-12-0580-RE

(C) 2013 The American Phytopathological Society vice versa (45). However, inoculations of those strains into almond trees produced no disease symptoms (33). Similarly $X$. fastidiosa subsp. fastidiosa cannot infect peach and plum $(15,17)$.

$X$. fastidiosa can be transmitted by at least six insect species of xylem-sap feeding sharpshooters (Hemiptera: Cicadellidae) and spittlebugs (Hemiptera: Cercopidae) $(4,5,26,30)$. Draeculacephala minerva Ball, a sharpshooter leafhopper that can transmit $X$. fastidiosa from almond to almond (26), was frequently found at the margins of almond orchards, with peak densities occurring during summer when $X$. fastidiosa titer is high in infected almond trees (8). D. minerva also was able to transfer a grape strain of $X$. fastidiosa from grape to almond trees $(11,21)$. Other leafhoppers, including Graphocephala atropunctata (Signoret), G. confluens (Uhler), and Carneocephala fulgida Nottingham, and the meadow spittlebug Philaenus spumarius L., are able to experimentally transmit ALS strains from almond to almond and from grape to almond (30). Introduction of the polyphagous glassy-winged sharpshooter (Homalodisca vitripennis) (42) into California circa $1989(40,41)$ has increased incidence of diseases caused by X. fastidiosa (5) because $H$. vitripennis readily feeds on more than 100 species of herbaceous and woody plants and its behavior is more dispersive than native California vectors $(1,18,27,28)$.

Control of diseases caused by $X$. fastidiosa is difficult due to the broad plant host range and abundance and diversity of $X$. fastidiosa insect vectors. Freezing temperatures have been shown to be therapeutic for PD (31) and ALS on potted almond trees (23) but cold therapy may have limited practical use in localities where almond trees are grown in California. Control of weeds that are reservoirs of $X$. fastidiosa (36) or breeding hosts for insect vectors (32) may be one practical management tool. Spread of plum leaf scald disease was decreased by soil applications of imidacloprid, a systemic and xylem-transported insecticide, for a period of 5 years (12). The fact that a period of 2 to 5 years occurs between the occurrence of ALS on a single branch to systemic infection of the whole tree (26) indicates that multiplication and movement of $X$. fastidios $a$ within 
the xylem of the tree is an important factor in disease development. Pruning of symptomatic branches infected with $X$. fastidiosa subsp. pauca has been reported as a cultural practice for the control of citrus variegated chlorosis in Brazil $(13,20)$. Severe pruning of newly infected almond limbs has shown some promise in preventing systemic infection of the pathogen, depending on the susceptibility of the particular almond cultivar (T. Cao and B. C. Kirkpatrick, unpublished data). We have PCR tested numerous peach leaves from rootstock suckers on almond trees expressing systemic ALS symptoms. In no case was $X$. fastidiosa detected in these peach leaves, suggesting that peach is immune to infection by strains of $X$. fastidiosa that cause ALS (24). In this study, we hypothesized that $X$. fastidiosa subsp. fastidiosa and X. fastidiosa subsp. multiplex could not pass through the xylem of almondpeach graft unions and survive in the peach rootstock. Thus, we tested the feasibility of using peach as a rootstock with a highgrafted almond scion scaffold system to prevent $X$. fastidiosa from spreading from almond scion limbs with ALS to scion limbs free of ALS.

\section{Materials and Methods}

Bacterial strains, culture conditions, and inoculum preparation. Strains of $X$. fastidiosa subsp. fastidiosa (Fetzer and Temecula) were routinely maintained in PD3 media (9) at $28^{\circ} \mathrm{C}$, and a strain of $X$. fastidiosa subsp. multiplex (Dixon) was grown in Periwinkle wilt $(\mathrm{PW})$ media $(10)$ at $28^{\circ} \mathrm{C}$. Strains Fetzer (14) and Temecula (43) were originally isolated from symptomatic, PDaffected grapevines in Napa Valley and Temecula Valley, respectively, and strain Dixon was isolated from an almond tree growing in Solano County, CA (14). X. fastidiosa long-term storage was at $-80^{\circ} \mathrm{C}$ in PD3 broth containing $15 \%$ glycerol for Fetzer and Temecula and in PW broth plus 15\% glycerol for Dixon. For bacterial inoculations, all three $X$. fastidiosa strains were grown separately, either in PD3 or PW liquid media for 10 days on a rotary shaker at $28^{\circ} \mathrm{C}$ or on PD3 or PW agar media for 2 weeks at $28^{\circ} \mathrm{C}$. $X$. fastidiosa cells grown in liquid media were harvested by centrifugation at $7,000 \times g$ for $10 \mathrm{~min}$ at $4^{\circ} \mathrm{C}$ and the bacterial pellet was suspended in $3 \mathrm{ml}$ of sterile deionized water $\left(\mathrm{sdH}_{2} \mathrm{O}\right)$. Strains grown on agar media were harvested by flooding the plate with $2 \mathrm{ml}$ of $\mathrm{sdH}_{2} \mathrm{O}$ and the cells were gently scraped from the medium using a glass spreader tool. The concentration of each $X$. fastidiosa strain was adjusted to approximately $10^{8}$ to $10^{9} \mathrm{CFU} / \mathrm{ml}$ by measuring the optical density at $600 \mathrm{~nm}$ with a spectrophotometer. To increase the chance of establishing $X$. fastidiosa infections, a combination of all three $X$. fastidiosa strains in equal concentration was used as the inoculum.

Plant materials and high-grafting. From February to May 2002, 1-year-old almond (Prunus dulcis (Mill.) D.A. Webb, 'NePlus' and 'Peerless') stems were high-grafted onto 2-year-old peach trees ( $P$. persica $(L$.) Batsch. 'Queencrest/Nemaguard') that were growing in the teaching orchard of the Department of Plant Sciences of the University of California, Davis. Four peach limbs of each tree were selected for grafting using either whip graft or chip budding of 1-year-old dormant almond scions. The graft union on each limb was at least $10 \mathrm{~cm}$ above the central tree trunk. After confirming successful grafting with the appearance of new almond shoots growing from the almond scion wood in May 2002, a perpendicular $\mathrm{V}$ training was performed to keep two peach scaffold limbs per tree with two current-season almond shoots per limb.

Bacterial inoculation of almond shoots. Bacterial inoculations were made by placing $20 \mu \mathrm{l}$ of bacterial suspension on a young stem and the bacterial drop was pierced with a fine needle into the shoot xylem, as described by Hopkins (16). The inoculum was typically drawn into the xylem transpirational stream within seconds after the needle inoculation. Two bacterial inoculations, 1.0 to $2.0 \mathrm{~cm}$ apart, were made on each almond shoot, and two new almond shoots of one peach limb were inoculated with bacteria on either 15 June or 15 July 2002, depending on the length of the new almond shoots. The remaining two almond shoots on the other peach scaffold limb of the same tree were left uninoculated and monitored for ALS symptoms to determine whether $X$. fastidiosa could move across the two almond-peach graft unions. In all, 10 NePlus and 6 Peerless trees were inoculated on 15 June 2002, and 5 trees each of NePlus and Peerless were inoculated on 15 July
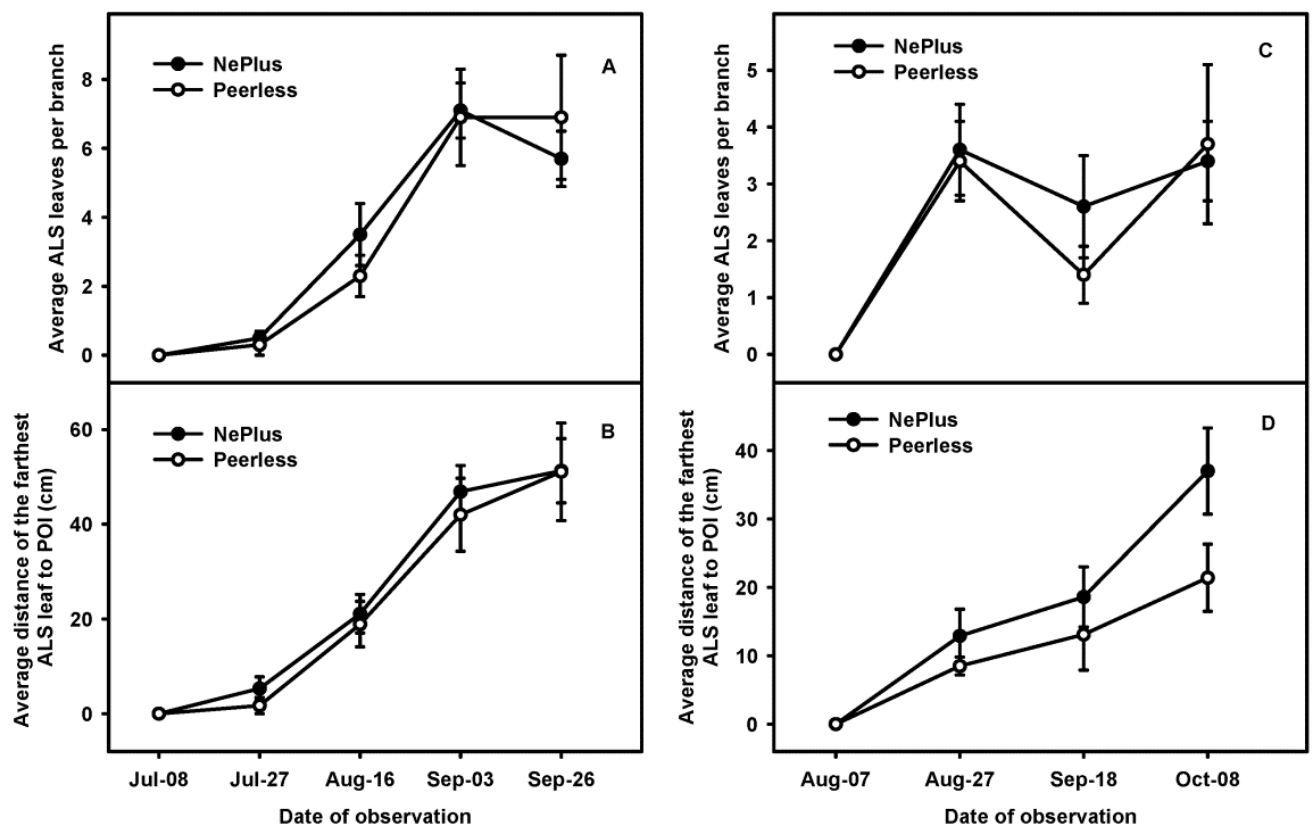

Fig. 1. Development of almond leaf scorch (ALS) following inoculation with cultured Xylella fastidiosa cells on $\mathbf{A}$ and B, 15 June 2002 and C and D, 15 July 2002 . On 15 June 2002, two current-year almond shoots were inoculated on one tree of each cultivar, for a total of 20 (NePlus) or 12 (Peerless) inoculated branches. A, Average numbers of leaves showing ALS symptoms averaged over 20 (NePlus) or 12 branches (Peerless). B, Distance (cm) of the farthest ALS symptomatic leaf to the point of inoculation (POI) averaged over 20 (NePlus) or 12 branches (Peerless). On 15 July 2002, two current-year almond shoots were inoculated on one tree, for a total of 10 inoculated branches of each cultivar. C, Average numbers of leaves showing ALS symptoms averaged over 10 branches. D, Distance $(\mathrm{cm})$ of the farthest ALS symptomatic leaf to the point of inoculation (POI) averaged over 10 branches of each cultivar. The decreased number of leaves with ALS on A, 26 September for NePlus and B, 18 September for both NePlus and C, Peerless indicated that some ALS-symptomatic leaves fell off or were removed for testing by immunocapture polymerase chain reaction. Error bars represent one standard error. 
2002; thus, a total of 15 NePlus and 11 Peerless trees were inoculated.

Disease evaluation and data analysis. ALS symptoms were monitored by recording the number of leaves with ALS symptoms on both the inoculated and uninoculated almond shoots every 3 weeks post inoculation. In September 2002, one to three ALSsymptomatic leaves from both the inoculated and uninoculated almond shoots were sampled to test for the presence of $X$. fastidiosa using an immunocapture polymerase chain reaction (IC-PCR) assay (39) using primers RST31 and RST33 (25), as described by Cao and co-workers (6). In some cases, the basal two leaves, which were the closest to the almond-peach graft union, on the uninoculated almond shoots were sampled for IC-PCR assay if no ALS symptoms developed on that uninoculated almond shoot. Some inoculated shoots expressing ALS were unable to be confirmed with the IC-PCR assay due to early defoliation in September 2002; such leaves were excluded from statistical analysis. Preliminary experiments showed that the IC-PCR assay consistently detected $X$. fastidiosa in a single ALS-symptomatic leaf with a fresh weight as low as $38 \mathrm{mg}$. In September 2003, only leaves with ALS symptoms were sampled for confirmation of $X$. fastidiosa infection using the IC-PCR assay. The Student's $t$ test was used for statistical significance when mean distances and percentiles were compared.

\section{Results}

ALS symptom development. ALS-symptomatic leaves were first observed on the inoculated shoots of NePlus and Peerless by the end of July following inoculation of $X$. fastidiosa on 15 June 2002 (Fig. 1A). Almond shoots inoculated on 15 July 2002 produced the first ALS-symptomatic leaves at the end of August 2002 for both cultivars (Fig. 1C). The incubation period for $X$. fastidiosa to cause typical ALS symptoms was about 6 weeks. The first leaves with ALS symptoms were generally within $20.0 \mathrm{~cm}$ from the inoculation site on the inoculated almond shoots. By early September 2002, typical ALS leaf symptoms were found on most of the inoculated NePlus and Peerless almond shoots that were inoculated on 15 June 2002 (Fig. 1A). For trees inoculated on 15 July 2002, typical ALS leaf symptoms were observed on most of the inoculated almond shoots for both cultivars in September and early October 2002. Overall, shoots inoculated on 15 June 2002 developed, on average, $6.1 \pm 0.8$ leaves (mean \pm standard error) per shoot with symptoms of ALS, which was significantly $(P=0.037)$ greater than $3.6 \pm 0.8$ leaves with ALS symptoms that developed on shoots inoculated on 15 July 2002. For each inoculation date (i.e., 15 June or 15 July 2002), there were no significant differences between NePlus and Peerless in the number of leaves with ALS symptoms per shoot.

Migration of $X$. fastidiosa within almond shoots. The distance $X$. fastidiosa moved within the inoculated shoots was estimated by measuring the distance of the most distant ALS-symptomatic leaf from the inoculation site. By the end of September 2002, shoots inoculated on 15 June 2002 , showed $51.3 \pm 6.8$ and $51.1 \pm 10.3 \mathrm{~cm}$ of bacterial migration (mean \pm standard error) in the inoculated shoots for NePlus and Peerless, respectively (Fig. 1B). By early October 2002, those shoots inoculated on 15 July 2002 showed $37.0 \pm 6.3$ and $21.4 \pm 4.9 \mathrm{~cm}$ of bacterial movement in the inoculated shoots for NePlus and Peerless, respectively (Fig. 1D). As indicated by the presence of the most distant leaves with ALS symptoms for both cultivars, bacteria migrated an average of 51.2 $\pm 5.6 \mathrm{~cm}$ in shoots inoculated on 15 June 2002, which was significantly $(P=0.008)$ greater than $29.2 \pm 4.3 \mathrm{~cm}$ in shoots inoculated on 15 July 2002. Migration distance of $X$. fastidiosa within shoots did not significantly differ between NePlus and Peerless regardless of the inoculation dates (data not shown).

By the end of the growing season of 2002, 87\% (26 of 30) of the inoculated NePlus shoots showed ALS symptoms and $82 \%$ of the 17 ALS-symptomatic shoots tested were IC-PCR positive for $X$. fastidiosa (Table 1). There were 14 uninoculated shoots that also had leaves with ALS symptoms (one to three leaves per shoot) in late August to early September 2002, and 5 of the shoots tested were IC-PCR positive for $X$. fastidiosa (Table 1). For Peerless, $82 \%$ (18 of 22) of the inoculated shoots developed ALS symptoms and $75 \%$ of the 12 ALS-symptomatic shoots tested were IC-PCR positive for $X$. fastidiosa (Table 1). One to three leaves with ALS symptoms also were observed on seven uninoculated Peerless shoots in late August to early September 2002, and three of the seven shoots tested positive for $X$. fastidiosa by IC-PCR (Table 1).

Distance between the two almond-peach graft unions was determined by measuring the length of peach stem section under the almond-peach graft unions. Student's $t$ test indicated that trees showing IC-PCR positive results on uninoculated shoots had a significantly $(P=0.046)$ shorter peach rootstock distance $(30.5 \pm$ $4.5 \mathrm{~cm}, n=8$ ) between the two almond-peach graft unions compared with those having IC-PCR negative results on uninoculated shoots $(46.1 \pm 4.5 \mathrm{~cm}, n=18)$.

ALS disease development on almond shoots that were inoculated in 2002 also was monitored in the growing season of 2003. For NePlus, no shoots with ALS symptoms were observed in 2003. However, 13 of the 18 ALS-symptomatic Peerless shoots observed in 2002 developed typical ALS symptoms in 2003 and all 13 shoots were PCR positive for $X$. fastidiosa. Of the 13 IC-PCRpositive shoots, 9 shoots were inoculated on 15 June 2002 and 4 were inoculated on 15 July 2002. Of the 14 NePlus and 7 Peerless shoots with ALS symptoms observed on the uninoculated shoots in 2002, no ALS symptoms were observed in September 2003. The overall ability of $X$. fastidiosa to overwinter in NePlus ( 0 of $26=$ $0 \%$ ) was significantly lower than in Peerless (13 of $18=72.2 \%, t=$ 5.165, $P<0.01)$.

\section{Discussion}

The data demonstrated that an incubation period of about 6 weeks post inoculation was necessary under field conditions for onset of ALS symptoms on leaves of the inoculated almond shoots, regardless of inoculation date. This is consistent with our previous observations that most of the almond cultivars develop ALS symptoms 4 to 10 weeks post inoculation (6). Previously, Davis and coworkers (11) inoculated almond shoot tips in March and June using a syringe injection method, and they found that ALS symptoms did not develop until October. Almeida and Purcell (3) inoculated $X$. fastidiosa isolates ALS4 and Contra Costa to NonPareil almond young stems, and found advanced symptoms of marginal necrosis 2 months after inoculation. Prado and coworkers (29) reported that inoculation of high concentrations of $X$. fastidiosa resulted in higher infection rates in citrus and coffee. In our experi-

Table 1. Almond leaf scorch (ALS) symptom development following mechanical inoculation of Xylella fastidiosa-cultured cells made on 15 June and 15 July 2002 on current-year almond shoots and results tested by X. fastidiosa-specific immunocapture polymerase chain reaction (IC-PCR) assay ${ }^{\mathrm{a}}$

\begin{tabular}{llcccc}
\hline & & \multicolumn{3}{c}{ Number of shoots } \\
\cline { 3 - 6 } Cultivar & Treatment & Total & With ALS-symptomatic leaves & PCR tested & IC-PCR positive \\
\hline NePlus & Inoculated & 30 & 26 & 17 & 14 \\
& Uninoculated & 30 & 14 & 12 & 5 \\
Peerless & Inoculated & 22 & 18 & 11 & 9 \\
& Uninoculated & 22 & 7 & 3 \\
\hline
\end{tabular}

\footnotetext{
${ }^{a}$ One to three leaves were collected from each shoot in September 2002 for IC-PCR assay. A few uninoculated shoots without ALS were also tested with IC-
} PCR when their adjacent inoculated shoots developed ALS symptoms. 
ments, we used high concentrations and large volumes of $X$. fastidiosa cells as inoculum. It is possible that this inoculation protocol accelerated development of ALS symptoms. In a previous study (3), inoculated almond plants were kept in a greenhouse with natural light and shortening photoperiod, which may have significantly reduced plant growth and slowed symptom development compared with our field experiment results. Similarly, Ledbetter and Rogers (24) reported that an incubation period of 11 weeks is required for $X$. fastidiosa-inoculated almond trees to develop ALS under greenhouse conditions. It is likely that differences in field and greenhouse environmental factors such as temperature, humidity, light intensity, and photoperiod as well as plant growth rates between field and greenhouses may have had a significant effect on the length of incubation period.

The presence of $X$. fastidiosa IC-PCR-positive ALS-symptomatic leaves on uninoculated shoots indicates within-plant movement of $X$. fastidiosa through the peach rootstock and both almond-peach graft unions. The significantly shorter distance of peach rootstock between the two almond-peach graft unions of trees with IC-PCR-positive results on uninoculated shoots compared with those with IC-PCR-negative results on uninoculated shoots indicates that the within-plant spread of $X$. fastidiosa occurred when there was a comparatively short distance separating the inoculated from the uninoculated shoot on the peach rootstock frame. The data also indicate that within-plant movement of $X$. fastidiosa in peach rootstocks occurred in both NePlus and Peerless varieties that were inoculated on 15 June and 15 July 2002, respectively. Thus, the within-plant movement of $X$. fastidiosa was not cultivar dependent if the bacterial inoculations were performed before the middle of July. We did not isolate X. fastidiosa from the petioles and midribs of the leaves because of slow growth of $X$. fastidiosa on solid medium and relatively high risk of contamination. Alternatively, the IC-PCR assay was adopted because it is faster and more sensitive compared with the isolation culture method (39).

$X$. fastidiosa populations did not survive the winter of 2002-03 in NePlus, because no ALS symptoms developed in fall 2003. The decreased number of inoculated Peerless shoots showing ALS symptoms in 2003 compared with 2002 indicates low overwinter survival of $X$. fastidiosa. Previously, Davis and coworkers (11), using both mechanical and leafhopper transmission inoculation procedures, inoculated 131 shoot tips in March and June and found that 31 of the 131 inoculated shoots developed ALS within 10 to $30 \mathrm{~cm}$ of the inoculation site on each branch by October. Nevertheless, only 2 of the 131 inoculated branches developed ALS in October of the following year. Our results are consistent with Davis et al. (11) and our previous study, which showed that $X$. fastidiosa could survive mild winters and cause ALS in some susceptible almond varieties after overwintering two or three seasons in California (6). It is not clear whether all three strains of $X$. fastidiosa were able to survive the winter of 2002-03 in the inoculated Peerless shoots because a mixture of all three strains was used as inoculum. Previously, Almeida and Purcell (3) found that isolates from grape overwintered with higher efficiency in grape than in almond and isolates from almond overwintered better in almond than in grape. Further bacterial isolation would provide direct evidence regarding the fate of all three $X$. fastidiosa strains in relation to their ability to overwinter in almond.

The data also demonstrated that survival of $X$. fastidiosa populations in NePlus was significantly lower than in Peerless. ALS has been observed on more than 10 commercially important almond varieties, including Nonpareil, Texas Mission, NePlus, and Peerless (34). Our previous research (6) demonstrated that Sonora, Solano, Peerless, Price, Mission, NePlus, Butte, Carmel, Padre, and Thompson almond varieties were susceptible to ALS when inoculated with $X$. fastidiosa in the first year. But chronic infections did not persist in Butte, Carmel, Padre, and Thompson 3 years post inoculation, and persistent infection tended to be less severe in NePlus than in Peerless (6). The results presented in this study are consistent with these previous findings (6).
Remission of ALS symptoms on uninoculated shoots in the second growing season suggests that the population of $X$. fastidiosa in the uninoculated shoots, due to systemic movement through a short distance in the peach rootstock, may not have allowed $X$. fastidiosa populations to survive the winter at high enough titers to cause ALS in the uninoculated almond shoots in the 2003 growing season. We did not collect leaf samples from those asymptomatic branches of inoculated shoots of NePlus and uninoculated branches of both NePlus and Peerless in the late season of 2003 for a further confirmation using IC-PCR assay, because previous work showed that $X$. fastidiosa could only be consistently isolated from plants expressing typical ALS foliar symptoms (11).

Collectively, the data allow us to hypothesize that systemic movement of $X$. fastidiosa through almond-peach graft unions was so limited that bacterial populations crossing the almond-peach graft unions could not survive the winter and subsequently cause ALS in the uninoculated almond shoots in the following year. This suggests that high-grafting almond scions on a peach rootstock scaffold might be an implementable management strategy to limit systemic movement of $X$. fastidiosa from one inoculated shoot to the rest of the almond branches grafted on the same peach rootstock. Currently, all available almond trees propagated by commercial nurseries are derived from a single almond bud that is lowgrafted on a peach, plum, or almond hybrid rootstock. If highgrafting of almond onto peach rootstock scaffolds is adopted as a strategy to deal with ALS, it may be advisable to insure that graft unions are at least $50 \mathrm{~cm}$ above the branching point of the rootstock.

\section{Acknowledgments}

We thank the California Almond Board for financial support and C. Vargas, M. C. Roper, M. Guilhabert, and D. D. Jones for providing technical assistance.

\section{Literature Cited}

1. Adlerz, W. C. 1980. Ecological observation on two leafhoppers that transmit the Pierce's disease bacterium. Proc. Fla. State Hortic. Soc. 93:115-120.

2. Aldrich, J. H., Gould, A. B., and Martin, F. G. 1992. Distribution of Xylella fastidiosa within roots of peach. Plant Dis. 76:885-888.

3. Almeida, R. P. P., and Purcell, A. H. 2003. Biological traits of Xylella fastidiosa strains from grapes and almonds. Appl. Environ. Microbiol. 69:7447-7452.

4. Almeida, R. P. P., and Purcell, A. H. 2003. Homalodisca coagulata (Hemiptera, Cicadellidae) transmission of Xylella fastidiosa to almond. Plant Dis. 87:1255-1259.

5. Almeida, R. P. P., and Purcell, A. H. 2003. Transmission of Xylella fastidiosa to grapevines by Homalodisca coagulata (Hemiptera: Cicadellidae). J. Econ. Entomol. 96:264-271.

6. Cao, T., Connel, J. H., Wilhelm, M., and Kirkpatrick, B. C. 2011. Influence of inoculation date on the colonization of Xylella fastidiosa and the persistence of almond leaf scorch disease among almond cultivars. Plant Dis. 95:158-165.

7. Chen, J., Groves, R., Civerolo, E. L., Viveros, A., Freeman, A., and Zheng, Y. 2005. Two Xylella fastidiosa genotypes associated with almond leaf scorch disease on the same location in California. Phytopathology 95:708714.

8. Daane, K. M., Wistrom, C. M., Shapland, E. B., and Sisterson, M. S. 2011. Seasonal abundance of Draeculacephala minerva and other Xylella fastidi$o s a$ vectors in California almond orchards and vineyards. J. Econ. Entomol. 104:367-374.

9. Davis, M. J., French, W. J., and Schaad, N. W. 1981. Axenic culture of the bacteria associated with phony peach disease and plum leaf scald. Curr. Microbiol. 6:309-314.

10. Davis, M. J., Raju, B. C., Brlansky, R. H., Lee, R. F., Timmer, I. W., Norris, R. C., and McCoy, R. E. 1983. Periwinkle wilt bacterium: axenic culture, pathogenicity, and relationships to other gram-negative, xylem-inhibiting bacteria, Phytopathology 73:1510-1515.

11. Davis, M. J., Thomson, S. V., and Purcell, A. H. 1980. Etiological role of a xylem-limited bacterium causing Pierce's disease in almond leaf scorch. Phytopathology 70:472-475.

12. Dutcher, J. D., Krewer, G, Chang, C. J., and Mullinix, B. 2002. Imidacloprid insecticide slows development of phony peach and plum leaf scald. Hortscience 37:749-750.

13. Garcia, A., Jr., Maggione, C. S., Teófilo Sobrinho J., Pompeu, J., Jr., Denegri, J. D., Quaggio, J. A., Beretta, M. J., Gravena, S., and Rodas, V. Z. 1995. Como conviver com a CVC em São Paulo. Laranja 16:145-154.

14. Hendson, M., Purcell, A. H., Chen, D., Smart, C., Guilhabert, M., and Kirkpatrick, B. C. 2001. Genetic diversity of Pierce's disease strains and other pathotypes of Xylella fastidiosa. Appl. Environ. Microbiol. 67:895-903. 
15. Hernandex-Martinez, R., Costa, H. S., Dumenyo, C. K., and Cooksey, D. A. 2006. Differentiation of strains of Xylella fastidiosa infection grape, almonds, and oleander using a multiprimer PCR assay. Plant Dis. 90:13821388.

16. Hopkins, D. L. 1988. Production of diagnostic symptoms of blight in citrus inoculated with Xylella fastidiosa. Plant Dis. 72:432-435.

17. Hopkins, D. L. 1989. Xylella fastidiosa: xylem-limited bacterial pathogen of plants. Annu. Rev. Phytopathol. 27:271-290.

18. Hopkins, D. L., and Purcell, A. H. 2002. Xylella fastidiosa: cause of Pierce's disease of grapevine and other emergent diseases. Plant Dis. 86:1056-1066.

19. Janse, J. D., and Obradovic, A. 2010. Xylella fastidiosa: its biology, diagnosis, control and risks. J. Plant Pathol. 92 (Suppl. 1):S1.35-S1.48.

20. Laranjeira, F. F., Silva, L. G., Fonseca, E. L., Silva, S. X. B., Rocha, J. B., Santos-Filho, H. P., Ledo, C. A. S., and Hau, B. 2008. Prevalence, incidence and distribution of citrus variegated chlorosis in Bahia, Brazil. Trop. Plant Pathol. 33:339-347.

21. Lopes, J. R. S., Daugherty, M. P., and Almeida, R. P. P. 2009. Contextdependent transmission of a generalist plant pathogen: Host species and pathogen strain mediate insect vector competence. Entomol. Exp. Appl. $131: 216-224$

22. Lopes, S. A., Marcussi, S., Torres, S. C. Z., Souza, V., Fagan, C., Franca, S. C. Fernandes, N. G., and Lopes, J. R. S. 2003. Weeds as alternative hosts of the citrus, coffee, and plum strains of Xylella fastidiosa in Brazil. Plant Dis. 87:544-549.

23. Ledbetter, C. A., Chen, J., Livingston, S., and Groves, R. L. 2009. Wintercuring of Prunus dulcis cv. 'Butte,' P. webbii and their interspecific hybrid in response to Xylella fastidiosa infections. Euphytica 169:113-122.

24. Ledbetter, C. A., and Rogers, E. E. 2009. Differential susceptibility of Prunus germplasm (subgenus Amygdalus) to a California strain of Xylella fastidiosa. HortScience. 44:1928-1931.

25. Minsavage, G. V., Thompson, C. M., Hopkins, D. L., Leite, R. M. V. B. C., and Stall, R. E. 1994. Development of a polymerase chain reaction protocol for detection of Xylella fastidiosa in plant tissue. Phytopathology 84:456-461.

26. Mircetich, S. M., Lowe, S. K., Moller, W. J., and Nyland, G. 1976. Etiology of almond leaf scorch disease and transmission of the causal agent. Phytopathology 66:17-24.

27. Mizell, R. F., III, and French, W. J. 1987. Leafhopper vectors of phony peach disease: feeding site preference and survival on infected and uninfected peach, and seasonal response to select host plants. J. Entomol. Sci. 22:11-22.

28. Mizell, R. F., III, Tipping, C., Andersen, P. C., Brodbeck, B., Hunter, W. B., and Northfield, T. 2008. Behavior model for Homalodisca vitripennis (Hemiptera: Cicadellidea): optimization of host plant utilization and management implication. Environ. Entomol. 37:1049-1062.

29. Prado, S. D., Lopes, J. R. S., Demetrio, C. G. B., Borgatto, A. F., and Almeida, R. P. P. 2008. Host colonization differences between citrus and coffee isolates of Xylella fastidiosa in reciprocal inoculation. Sci. Agric. 65:251-258.

30. Purcell, A. H. 1980. Almond leaf scorch: leafhopper (Homoptera: Cicadellidae) and spittlebug (Homoptera: Cercopidae) vectors. J. Econ. Entomol. 73:834-838.

31. Purcell, A. H. 1980. Environmental therapy for Pierce's disease of grapevines. Plant Dis. 64:388-390.

32. Purcell, A. H., and Saunders, S. R. 1999. Fate of Pierce's disease strains of Xylella fastidiosa in common riparian plants in California. Plant Dis.
83:825-830.

33. Raju, B. C., Wells, J. M., Nyland, G., Brlansky, R. H., and Lowe, S. K. 1982. Plum leaf scald isolation culture and pathogenicity of the causal agent. Phytopathology 72:1460-1466.

34. Sanborn, R. R., Mircetich, S. M., Nyland, G., and Moller, W. J. 1974 "Golden death" a new leaf scorch threat to almond growers. Calif. Agric. 28:4-5.

35. Schaad, N. W., Postnikova, E., Lacy, G., Fatmi, M, Chang, C. J. 2004. Xylella fastidiosa subspecies: X. fastidiosa subsp. piercei, subsp. nov., $X$. fastidiosa subsp. multiplex subsp. nov., and X. fastidiosa subsp. pauca subsp. nov. Syst. Appl. Microbiol. 27:290-300.

36. Shapland, E. B., Daane, K. M., Yokota, G. Y, Wistrom, C., Connell, J. H Duncan, R. A., and Viveros, M. A. 2006. Ground vegetation survey for $X y$ lella fastidiosa in California almond orchards. Plant Dis. 90:905-909.

37. Sisterson, M. S., Chen, J., Civerolo, E. L., Ledbetter, C. A., and Groves, R. L. 2008. Effects of almond leaf scorch disease on almond yield and implications for management. Plant Dis. 92:409-414.

38. Sisterson, M. S., Ledbetter, C. A., Higbee, B., Groves, R., Chen, J., and Daane, K. 2012. Management of almond leaf scorch disease: long term data on yield, tree vitality, and disease progress. Plant Dis. 96:1037-1044.

39. Smart, C. D., Hendson, M., Guilhabert, M. R., Saunders, S., Friebertshauser, G., Purcell, A. H., and Kirkpatrick, B. C. 1998. Seasonal detection of Xylella fastidiosa in grapevines with culture, ELISA and PCR. (Abstr.) Phytopathology 88:S83.

40. Sorensen, J. T., and Gill, R. J. 1996. A range extension of Homalodisca coagulata (Say) (Hemiptera: Clypeorrhyncha: Cicadellidae) to southern California. Pan-Pac. Entomol. 72:160-161.

41. Stenger, D. C., Sisterson, M. S., and French, R. 2010. Population genetics of Homalodisca vitripennis reovirus validates timing and limited introduction to California of its invasive insect host, the glassy-winged sharpshooter Virology 407:53-59.

42. Takiya, D. M., McKamey, S. H., and Cavichiloi, R. R. 2006. Validity of Homalodisca and of $H$. vitripennis as the name for glassywinged sharpshooter (Hemiptera: Cicadellidae: Cicadellinae). Ann. Entomol. Soc. Am. 99:648-655.

43. Van Sluys, M. A., de Oliveira, M. C., Monteiro-Vitorello, C. B., Miyaki, C. Y., Furlan, L. R., Camargo, L. E. A., da Silva, A. C. R., Moon, D. H., Takita, M. A., Lemos, E. G. M., Machado, M. A., Ferro, M. I. T., da Silva, F. R., Goldman, M. H. S., Goldman, G. H., Lemos, M. V. F., El-Dorry, H., Tsai, S. M., Carrer, H., Carraro, D. M., de Oliveira, R. C., Nunes, L. R., Siqueira, W. J., Coutinho, L. L., Kimura, E. T., Ferro, E. S., Harakava, R., Kuramae, E. E., Marino, C. L., Giglioti, E., Abreu, I. L., Alves, L. M. C., do Amaral, A. M., Baia, G. S., Blanco, S. R., Brito, M. S., Cannavan, F. S. Celestino, A. V., da Cunha, A. F., Fenille, R. C., Ferro, J. A., Formighieri, E. F., Kishi, L. T., Leoni, S. G., Oliveira, A. R., Rosa, V. E., Jr., Sassaki, F. T., Sena, J. A. D., de Souza, A. A., Truffi, D., Tsukumo, F., Yanai, G. M., Zaros, L. G., Civerolo, E. L., Simpson, A. J. G., Almeida, N. F., Setubal, J. C., and Kitajima, J. P. 2003. Comparative analyses of the complete genome sequences of Pierce's disease and citrus variegated chlorosis strains of Xylella fastidiosa. J. Bacteriol. 185:1018-1026.

44. Wells, J. M., Raju, B. C., Hung, H. Y., Weisburg, W. G., Mandelco-Paul, L. and Brenner, D. J. 1987. Xylella fastidiosa new-genus new species Gramnegative xylem-limited fastidious plant bacteria related to Xanthomonasspp. Int. J. Syst. Bacteriol. 37:136-143.

45. Wells, J. M., Raju, B. C., Thompson, J. M., and Lowe, S. K. 1981. Etiology of phony peach and plum leaf scald disease. Phytopathology 71:1156-1161. 